\title{
Diabetic retinopathy is associated with oxidative stress and mitigation of gene expression of antioxidant enzymes
}

This article was published in the following Dove Press journal:

International Journal of General Medicine

18 September 2013

Number of times this article has been viewed

\author{
Mohamed Fath El-Bab ${ }^{1,4}$ \\ Nashaat S Zaki ${ }^{2,5}$ \\ Moaz A Mojaddidi' \\ Maan AL-Barry ${ }^{2}$ \\ Hesham A El-Beshbishy ${ }^{3,6}$ \\ 'Department of Physiology, Taibah \\ University, Almadinah, Kingdom \\ of Saudi Arabia; ${ }^{2}$ Department of \\ Ophthalmology, College of Medicine, \\ Taibah University, Almadinah, Kingdom \\ of Saudi Arabia; ${ }^{3}$ Department of \\ Medical Laboratories Technology, \\ Faculty of Applied Medical Sciences, \\ Taibah University, Almadinah, Kingdom \\ of Saudi Arabia; ${ }^{4}$ Department of \\ Physiology, Faculty of Medicine, \\ Suez Canal University, Ismailia, Egypt; \\ ${ }^{5}$ Department of Ophthalmology, \\ Faculty of Medicine, Mansoura \\ University, Mansoura, Egypt; \\ ${ }^{6}$ Biochemistry Department, Faculty \\ of Pharmacy, Al-Azhar University, \\ Nasr City, Cairo, Egypt
}

\begin{abstract}
Type 2 diabetes is a metabolic disease associated with serious complications, including diabetic retinopathy (DR). The authors' main aim was to investigate biochemical parameters and the oxidative stress associated with the type 2 DR patients and to study gene expression of superoxide dismutase (SOD), catalase (CAT), and glutathione peroxidase (GPx) among patients with DR $[\mathrm{DR}(+)]$ compared with a control nondiabetic group. In all, 67 patients with DR included in this study were diabetic for more than 10 years. Among them, 22 patients were $\mathrm{DR}(+)$, and 45 patients did not have DR [DR(-)]. The subjects' age range was 14 years to 80 years old with diabetes duration range between 2 and 45 years. Body mass index (BMI) was $31.43 \pm 5.94$ and $32.33 \pm 6.54$, systolic blood pressure was $117.15 \pm 18.16 \mathrm{mmHg}$ and $126.15 \pm 20.26 \mathrm{mmHg}$, diastolic blood pressure was $81.11 \pm 10.55 \mathrm{mmHg}$ and $82.77 \pm 10.85 \mathrm{mmHg} \mathrm{HbA}_{1 \mathrm{c}}$ was $7.2 \pm 1.1$ and $8.19 \pm 1.95$, serum total cholesterol was $6.61 \pm 1.11$ and $4.11 \pm 0.31$, serum triglycerides were $3.52 \pm 0.89$ and $3.42 \pm 0.79$, serum low-density lipoprotein (LDL) was $2.12 \pm 0.10$ and $2.42 \pm 0.15$, high-density lipoprotein (HDL) was $2.66 \pm 0.30$ and $2.55 \pm 0.21$, SOD was $3.12 \pm 0.87$ and $1.53 \pm 0.14$, GPx was $11.14 \pm 2.21$ and $8.2 \pm 1.84$, CAT was $26.43 \pm 3.34$ and $9.60 \pm 2.14$, for $\mathrm{DR}(-)$ and $\mathrm{DR}(+)$ patients, respectively. SOD, GPx and CAT polymerase chain reaction (PCR) products of the $\mathrm{DR}(+)$ patients revealed the diminished expression of CAT gene followed by GPx and SOD genes. All were significant compared with the normal controls, $P<0.05$. Linear regression analysis revealed a strong significant positive correlation between the retinopathy grade and the diastolic blood pressure, diabetes duration, hemoglobin $\mathrm{A} 1 \mathrm{c}\left(\mathrm{HA}_{1 \mathrm{c}}\right) \%$, and fasting blood glucose $(P<0.001)$. A marginally significant positive correlation between the retinopathy grade and LDL-cholesterol was observed $(P<0.05)$, and a significant negative correlation between the retinopathy grade and total cholesterol was observed $(P<0.05)$. Poor glycemic control and alteration in mRNA gene expression of antioxidant enzymes are strongly associated with development of DR and the regular screening is mandatory for early detection and treatment.
\end{abstract}

Keywords: diabetic retinopathy, antioxidant enzymes, gene expression

\section{Introduction}

Type 2 diabetes is a metabolic disease associated with serious micro- and macrovascular complications, including diabetic retinopathy (DR), that are aggravated by poor glycemic control, hypertension, and longer disease duration. ${ }^{1} \mathrm{DR}$ is associated with a strong genetic predisposition, highlighted by the familial clustering of DR. ${ }^{2,3}$

Diabetic retinopathy is a common and highly specific microvascular complication of diabetes mellitus and represents the leading cause of blindness among workingage individuals in developed countries. ${ }^{4}$ DR occurs both in type 1 and type 2 diabetes and is strictly related to disease duration: virtually all individuals diagnosed with
Correspondence: Mohamed Fath El-Bab Department of Physiology,

Taibah University, PO Box 3000I, Almadinah, Kingdom of Saudi Arabia Email mfeb70@hotmail.com 
diabetes at less than 30 years of age and more than $70 \%$ of individuals diagnosed aged 30 years or older develop DR after 15 years of diabetes duration. ${ }^{5,6}$ However, there are substantial differences between type 1 and type 2 diabetes in terms of clinical presentation, prevalence, and, at least in part, risk factors of DR.

Prevalence of any DR is higher in type 1 than in type 2 diabetes and also in males than in females. ${ }^{7}$ However, prevalence estimates are quite variable across the world, and it is unclear whether recent improvements in diabetes care have resulted in significant reduction of this complication, and particularly, of its sight-threatening lesions. ${ }^{8}$ Reanalysis of individuals under poor control in 25 years of follow-up revealed only minor improvements following implementation of improved care, even though an intensive glucose control early in the course of the disease produced significant and persistent benefits on microvascular complications including DR, both in type 1 and in type 2 diabetes. ${ }^{9-11}$ In addition to the extent and duration of chronic hyperglycemia, other risk factors for DR are dyslipidemia and hypertension; however, the role of age, gender, and smoking is controversial and seems to differ between type 1 and type $2 .^{12-16}$

The aim of the present study was to investigate different anthropometric and biochemical parameters among patients with DR $[\mathrm{DR}(+)]$ and patients without DR $[\mathrm{DR}(-)]$. These included age, diabetes onset and duration, fasting and postprandial glucose, systolic and diastolic blood pressure (BP). Blood $\mathrm{HA}_{1 \mathrm{c}}$ was measured as were serum triglycerides, total and high-density lipoprotein (HDL) cholesterol, and low-density lipoprotein (LDL) cholesterol. The antioxidant enzymes such as glutathione peroxidase (GPx), catalase (CAT), and superoxide dismutase (SOD) were measured. A polymerase chain reaction (PCR) was also performed to quantify the expression of messenger ribonucleic acid (mRNA) for the SOD, GPx and CAT antioxidant enzymes.

\section{Subjects, materials, and methods}

The proposal of the following prospective study was approved by the local ethics committee; written informed consent was obtained from each patient who attended the outpatient clinic of the Diabetic Patients Medical Centre in King Fahad Hospital in Al-Madinah Al-Munawarah, in Kingdom of Saudia Arabia in the academic year 2011-2012. All diabetic subjects were diagnosed using international standard criteria published by the American Diabetes Association. ${ }^{17,18}$ The DR assessment was carried out according to the Diabetic
Retinopathy Grading of Tam et al in $2009^{19}$ and Wilkinson et al in $2003 .^{20}$

\section{Chemicals and kits}

Chemicals and reagents were of the highest analytical grade and purchased from the Sigma-Aldrich (St Louis, MO, USA). Diagnostic kits for $\mathrm{HA}_{1 \mathrm{c}}$ were purchased from NS BIOTEC (London, UK). Diagnostic kits for serum triglycerides, and total and HDL-cholesterol, were purchased from Randox Laboratories Ltd., (London, UK). Diagnostic kits for serum CAT and SOD were purchased from Cell Biolabs Inc (San Diego, CA, USA). The serum GPx activity assay kit was purchased from BioVision Inc., (Milpitas, CA, USA). The RNA extraction kit was supplied from Promega UK Ltd (Southampton, UK). The primers for SOD, GPx and CAT genes were synthesized and purchased from TIB Molbiol GmbH (Berlin, Germany).

\section{Patients and biochemical parameters}

The 67 patients with non-insulin-dependent diabetic retinopathy used in this study were diabetic for more than 10 years. All patients filled out a structured questionnaire to collect the following information: age; diabetes onset and duration; fasting and postprandial glucose using the glucose oxidase method; systolic and diastolic blood pressure (BP) using the Richter ${ }^{\circledR}$ mercurial sphygmomanometer after 5 minutes of rest. Fresh blood samples were used for the determination of $\mathrm{HA}_{1 \mathrm{c}}$. Blood samples were withdrawn from the vein into a BD Vacutainer tube containing anticoagulant and sodium fluoride, followed by centrifugation at $6000 \mathrm{rpm}$ for 10 minutes. The resulting supernatant was used for the determination of serum triglycerides, total and HDL cholesterol using standard analytical methods. However, the LDL cholesterol was calculated by the Friedwald formula. ${ }^{21}$

The serum GPx activity was determined by a spectrophotometric method based on the oxidation of GSH by GPx in the presence of hydrogen peroxide to produce glutathione disulfide (GSSG). Then, nicotinamide adenine dinucleotide phospate (NADPH) and GR were used for production of glutathione (GSH) and NADP. Enzyme activity was determined by measuring the disappearance on NADPH at $340 \mathrm{~nm}$ and was expressed as $\mathrm{mU} / \mathrm{mL}{ }^{22}$ Serum CAT enzyme activity was determined by spectrophotometric method that based on the fact that, catalase catalyzes the breakdown of $\mathrm{H}_{2} \mathrm{O}_{2}$. The remaining $\mathrm{H}_{2} \mathrm{O}_{2}$ in the reaction mixture facilitates the coupling of this reaction monitored at $520 \mathrm{~nm}$. The decrease 
in absorbance is proportional to the activity of CAT. ${ }^{23} \mathrm{CAT}$ activity was expressed as $\mathrm{U} / \mathrm{mL}$. The serum SOD activity was determined at $37^{\circ} \mathrm{C}$ by the xanthine/xanthine oxidase system that generates the superoxide anions. The presence of SOD resulted in the decrease of superoxide anions yielding a lower colorimetric signal at $490 \mathrm{~nm}$. SOD was expressed as $\mathrm{U} / \mathrm{mL} .^{24}$

\section{Reverse-transcriptase (RT)-PCR of SOD, CAT and GPX}

RNA was extracted from the blood; $1 \mu \mathrm{g}$ of the extracted mRNA was denatured at $72^{\circ} \mathrm{C}$ for 10 minutes and reversibly transcribed to cDNA by incubating with a reaction mixture containing $50 \mathrm{mM}$ Tris- $\mathrm{HCl}, 75 \mathrm{mM} \mathrm{KCl}, 3 \mathrm{mM} \mathrm{MgCl}{ }_{2}$, $10 \mathrm{mM}$ DTT, $0.5 \mathrm{mM}$ of each dNTP, $62.5 \mathrm{mU}$ DNase I, $50 \mathrm{ng}$ random hexamers, and $100 \mathrm{U} \mathrm{M}-\mathrm{MuLV}$ reverse transcriptase (RT). The reaction mixture was then incubated at $42^{\circ} \mathrm{C}$ for 60 minutes, heated to $95^{\circ} \mathrm{C}$ for 5 minutes, and then quickly chilled on ice. The PCR was performed to quantify the expression of mRNA for the antioxidant enzymes (SOD, GPx and CAT). The cDNA $(2 \mu \mathrm{L})$ was amplified in a $50 \mu \mathrm{L}$ of PCR reaction mixture containing $10 \times \mathrm{PCR}$ reaction buffer, $25 \mathrm{mM} \mathrm{MgCl}_{2}, 4 \mathrm{mM}$ dNTPs, and $15 \mu \mathrm{M}$ each primer and 7 Unit Taq DNA polymerase. The primers' design was optimized using the (Applied Biosystems, Life Technologies, Carlsbad, CA, USA) and listed in Table 1. The PCR thermal cycler (Swift Maxi thermal cycler, ESCO Technologies Inc, St Louis, MO, USA) was programmed as follows: denaturation step at $95^{\circ} \mathrm{C}$ for 2 minutes followed by 30 cycles of $95^{\circ} \mathrm{C}$ for 1 minute; $55^{\circ} \mathrm{C}$ for 1 minute and $72^{\circ} \mathrm{C}$ for 30 seconds. A final extension cycle at $72^{\circ} \mathrm{C}$ for 3 minutes was performed. The PCR products were analyzed on a $2 \%$ agarose gel and visualized under a ultra violet transilluminator.

Table I Primer sequences and the expected size of the PCR product for the antioxidant enzymes; SOD, GPx, and CAT ${ }^{45}$

\begin{tabular}{|c|c|c|c|}
\hline Gene & Primer & Sequence $5^{\prime}-3^{\prime}$ & $\begin{array}{l}\text { Product } \\
\text { size }\end{array}$ \\
\hline \multirow[t]{2}{*}{ SOD } & $\mathrm{F}$ & 5'-GCAGAAGGCAAGCGGTGAAC-3' & $387 \mathrm{bp}$ \\
\hline & $\mathrm{R}$ & 5'-TAGCAGGACAGCAGATGAGT-3' & \\
\hline \multirow[t]{2}{*}{ GPx } & $\mathrm{F}$ & 5'-CTCTCCGCGGTGGCACAGT-3' & $29 \mathrm{bp}$ \\
\hline & $\mathrm{R}$ & 5'-CCACCACCGGGTCGGACATAC-3' & \\
\hline \multirow[t]{3}{*}{ CAT } & $\mathrm{F}$ & 5'-GCGAATGGAGAGGCAGTGTAC-3' & $670 \mathrm{bp}$ \\
\hline & $\mathrm{R}$ & 5'-GAGTGACGTTGTCTTCATTAG & \\
\hline & & CACTG-3' & \\
\hline
\end{tabular}

Abbreviations: bp, base pair; SOD, superoxide dismutase; GPx, glutathione peroxidase; CAT, catalase.

\section{Assessment of DR}

The presence of DR was assessed by an expert ophthalmologist using dilated fundoscopy. Patients were classified into the following categories: absent DR; mild, moderate or severe non-proliferative diabetic retinopathy; proliferative diabetic retinopathy (PDR); or maculopathy according to the Global Diabetic Retinopathy Project Group. ${ }^{19,20}$ DR grade was assigned based on the worst eye (Table 2).

\section{Statistical analysis}

Results are reported as mean \pm standard deviation (SD). Statistical analysis was performed using one-way analysis of variance (ANOVA). If the overall $P$-value was found to be statistically significant $(P<0.05)$, further comparisons among groups were made according to the post hoc Tukey's procedure multiple comparison test, and linear regression analysis. All statistical analyses were performed using GraphPad InStat 3 (GraphPad Software, Inc, La Jolla, CA, USA) software. Graphs were sketched using GraphPad Prism version 4 software.

\section{Results}

In this study, we examined 67 diabetic patients for the existence of DR. Twenty-two (32.84\%) patients were $\mathrm{DR}(+)$, and $45(67.16 \%)$ patients were DR(-). Our data

Table 2 Diabetic retinopathy patient distributions in the present study population according to the Global Diabetic Retinopathy Project grading ${ }^{19,20}$

\begin{tabular}{|c|c|c|c|}
\hline Score & $\begin{array}{l}\text { International } \\
\text { term }\end{array}$ & Description & $\begin{array}{l}\text { DR patients } \\
n=67\end{array}$ \\
\hline Grade 0 & No PDR & $\begin{array}{l}\text { Normal retina } \\
\text { (Background } \\
\text { retinopathy) }\end{array}$ & 45 (46.16\%) \\
\hline Grade I & $\begin{array}{l}\text { Mild non- } \\
\text { proliferative }\end{array}$ & $\begin{array}{l}\text { Hgs and MA only, } \\
\text { very minor IRMAs }\end{array}$ & 8 (11.94\%) \\
\hline Grade 2 & $\begin{array}{l}\text { Moderate non- } \\
\text { proliferative }\end{array}$ & $\begin{array}{l}\text { Extensive MA, } \\
\text { intra-retinal Hgs, } \\
\text { and hard exudates }\end{array}$ & $6(8.96 \%)$ \\
\hline Grade 3 & $\begin{array}{l}\text { Severe non- } \\
\text { proliferative }\end{array}$ & $\begin{array}{l}\text { Venous abnormalities, } \\
\text { large blot Hgs, cotton } \\
\text { wool spots, venous } \\
\text { beading, venous loop, } \\
\text { venous reduplication, } \\
\text { IRMAs }\end{array}$ & $5(7.46 \%)$ \\
\hline Grade 4 & $\begin{array}{l}\text { Proliferative } \\
\text { retinopathy }\end{array}$ & $\begin{array}{l}\text { New vessel formation } \\
\text { either at the disc } \\
\text { neovascularization } \\
\text { or elsewhere }\end{array}$ & 3 (4.48\%) \\
\hline
\end{tabular}

Abbreviations: DR, diabetic retinopathy; PDR, proliferative diabetic retinopathy; Hgs, hemorrhages; MA, micro-aneurysm; IRMAs, intra-retinal micro-vascular abnormalities. 
revealed the following positive diabetic retinopathy patient distribution: grade I, eight patients; grade II, six patients; grade III, five patients; and grade IV in three patients, representing $36.4 \%, 27.3 \%, 22.7 \%$ and $13.6 \%$ of the 22 $\mathrm{DR}(+)$ patients, respectively (Table 2). Patients with DR $(\mathrm{n}=22$ ) were 14 to 80 -years-old and had a diabetes duration of 2 to 45 years. The body mass index (BMI) of DR(-) and $\mathrm{DR}(+)$ patients was $31.43 \pm 5.94$ and $32.33 \pm 6.54$, respectively. The systolic blood pressure changed significantly, from $109 \pm 18.46 \mathrm{mmHg}$ among normal controls to $117.15 \pm 18.16 \mathrm{mmHg}$ and $126.15 \pm 20.26 \mathrm{mmHg}$ for $\mathrm{DR}(-)$ and DR(+) patients, respectively. The diastolic blood pressure) changed significantly from $76.77 \pm 10.55 \mathrm{mmHg}$ among normal controls to $81.11 \pm 10.55 \mathrm{mmHg}$ and $82.77 \pm 10.85 \mathrm{mmHg}$ for $\mathrm{DR}(-)$ and $\mathrm{DR}(+)$ patients, respectively.

The fasting blood glucose changed significantly from $74.21 \pm 11.61 \mathrm{mg} \%$ among normal controls to $142.81 \pm 31.41 \mathrm{mg} \%$ and $143.21 \pm 37.33 \mathrm{mg} \%$, for DR(-) and DR(+) patients, respectively. The postprandial blood glucose changed significantly from $105 \pm 23.21 \mathrm{mg} \%$ among normal controls to $170.22 \pm 43.33 \mathrm{mg} \%$ and $174.22 \pm 73.33 \mathrm{mg} \%$, for $\mathrm{DR}(-)$ and $\mathrm{DR}(+)$ patients, respectively. The $\mathrm{HA}_{1 \mathrm{c}}$ changed significantly from $3.29 \pm 0.95 \mathrm{mg} \%$ among normal controls to $7.2 \pm 1.1 \mathrm{mg} \%$ and $8.19 \pm 1.95 \mathrm{mg} \%$, for $\mathrm{DR}(-)$ and $\mathrm{DR}(+)$ patients, respectively (Table 3 ). The serum total cholesterol changed significantly from $2.61 \pm 0.54 \mathrm{mmol} / \mathrm{L}$ among normal controls to $6.61 \pm 1.11 \mathrm{mmol} / \mathrm{L}$ and $4.11 \pm 0.31 \mathrm{mmol} / \mathrm{L}$ for $\mathrm{DR}(+)$ and $\mathrm{DR}(-)$ patients, respectively. The serum trig-

Table 3 Basic clinical biochemical parameters of diabetic retinopathy patients

\begin{tabular}{|c|c|c|c|}
\hline & $\begin{array}{l}\text { NC } \\
n=2 I \\
(\text { Mean } \pm S D)\end{array}$ & $\begin{array}{l}\text { DR(-) } \\
n=45 \\
(\text { Mean } \pm \text { SD) }\end{array}$ & $\begin{array}{l}\text { DR(+) } \\
n=22 \\
(\text { Mean } \pm \text { SD) }\end{array}$ \\
\hline Age (years) & $38.33 \pm 10.22$ & $40.56 \pm 11.5 I^{*}$ & $42.33 \pm 12.44 *$ \\
\hline $\begin{array}{l}\text { Duration of } \\
\text { diabetes (years) }\end{array}$ & - & $11.29 \pm 3.43^{*}$ & $10.29 \pm 3.28^{*}$ \\
\hline $\begin{array}{l}\text { Body mass index } \\
\left(\mathrm{kg} / \mathrm{m}^{2}\right)\end{array}$ & $29.33 \pm 5.94$ & $31.43 \pm 5.94 *$ & $32.33 \pm 6.54^{*}$ \\
\hline $\begin{array}{l}\text { Systolic blood } \\
\text { pressure }(\mathrm{mmHg})\end{array}$ & $109.34 \pm 18.46$ & $117.15 \pm 18.16^{*}$ & $126.15 \pm 20.26^{*}$ \\
\hline $\begin{array}{l}\text { Diastolic blood } \\
\text { pressure }(\mathrm{mmHg})\end{array}$ & $76.77 \pm 10.55$ & $81.11 \pm 10.55^{*}$ & $82.77 \pm 10.85^{*}$ \\
\hline $\begin{array}{l}\text { Glycated } \\
\text { hemoglobin }\left(\mathrm{HA}_{\mathrm{Ic}}\right)\end{array}$ & $3.29 \pm 0.95$ & $7.20 \pm 1 . I^{*}$ & $8.19 \pm 1.95^{*}$ \\
\hline
\end{tabular}

Notes: Values are expressed as mean \pm SD. *Significant change difference from normal control group at $P<0.05$.

Abbreviations: NC, normal control group; DR(-), diabetics without retinopathy; $\mathrm{DR}(+)$, diabetics with retinopathy; SD, standard deviation. lycerides changed significantly from $2.52 \pm 0.23 \mathrm{mmol} / \mathrm{L}$ among normal controls to $3.52 \pm 0.89 \mathrm{mmol} / \mathrm{L}$ and $3.42 \pm 0.79 \mathrm{mmol} / \mathrm{L}$ for $\mathrm{DR}(+)$ and $\mathrm{DR}(-)$ patients, respectively. The serum LDL-cholesterol changed significantly from $1.52 \pm 0.12 \mathrm{mmol} / \mathrm{L}$ among normal controls to $2.12 \pm 0.10 \mathrm{mmol} / \mathrm{L}$ and $2.42 \pm 0.15 \mathrm{mmol} / \mathrm{L}$ for DR(-) and DR(+) patients. The serum HDL cholesterol changed significantly from $2.85 \pm 0.13 \mathrm{mmol} / \mathrm{L}$ among normal controls to $2.66 \pm 0.30 \mathrm{mmol} / \mathrm{L}$ and $2.55 \pm 0.21 \mathrm{mmol} / \mathrm{L}$, for DR(-) and DR(+) patients, respectively (Table 4).

The serum SOD changed significantly from $5.44 \pm$ $1.12 \mathrm{U} / \mathrm{mL}$ among normal controls to $3.12 \pm 0.87 \mathrm{U} / \mathrm{mL}$ and $1.53 \pm 0.14 \mathrm{U} / \mathrm{mL}$, for $\mathrm{DR}(-)$ and $\mathrm{DR}(+)$ patients. The serum GPx changed significantly from $14.31 \pm 3.14 \mathrm{mU} / \mathrm{mL}$ among normal controls to $11.14 \pm 2.21 \mathrm{mU} / \mathrm{mL}$ and $8.2 \pm 1.84 \mathrm{mU} /$ $\mathrm{mL}$, for $\mathrm{DR}(-)$ and $\mathrm{DR}(+)$ patients, respectively. The serum CAT was significantly changed from $40.13 \pm 5.94 \mathrm{U} / \mathrm{mL}$ in case of normal control to $26.43 \pm 3.34 \mathrm{U} / \mathrm{mL}$ and $9.60 \pm 2.14 \mathrm{U} / \mathrm{mL}$, for DR(-) and DR(+) patients, respectively (Table 5). The agarose gel electrophoresis pattern of the SOD, GPx, and CAT PCR products of the DR $(+)$ patients revealed the diminished expression of the CAT gene, followed by GPx and SOD genes (Figure 1).

The linear regression analysis among different biochemical parameters in DR patients revealed a strong significant positive correlation between the retinopathy grade $(\mathrm{RG})$ and the diastolic blood pressure $\left(r^{2}=+0.49 ; P<0.001\right)$, diabetes duration $\left(r^{2}=0.3593 ; P<0.001\right), \mathrm{HA}_{1 \mathrm{c}} \%\left(r^{2}=+0.1472\right.$, $P<0.0001)$ and fasting blood glucose $\left(r^{2}=+0.1626\right.$, $P<0.0001)$. A slightly significant positive correlation

Table 4 Lipid profile of diabetic patients

\begin{tabular}{|c|c|c|c|}
\hline & $\begin{array}{l}N C \\
n=2 I\end{array}$ & $\begin{array}{l}\text { DR(-) } \\
n=45\end{array}$ & $\begin{array}{l}\text { DR(+) } \\
n=22\end{array}$ \\
\hline \multicolumn{4}{|c|}{ Total cholesterol (mmol/L) } \\
\hline Range & $0.30-4.7$ & $0.28-6.3$ & $0.48-9.4$ \\
\hline Mean \pm SD & $2.61 \pm 0.54$ & $4.1 I \pm 0.31$ & $6.61 \pm 1.11 *$ \\
\hline \multicolumn{4}{|c|}{ Triglycerides $(\mathrm{mmol} / \mathrm{L})$} \\
\hline Range & $0.34-3.8$ & $0.45-7.8$ & $0.34-9.8$ \\
\hline Mean \pm SD & $2.52 \pm 0.23$ & $3.42 \pm 0.79 *$ & $3.52 \pm 0.89 *$ \\
\hline \multicolumn{4}{|c|}{ LDL-cholesterol (mmol/L) } \\
\hline Range & $0.3 I-3.5$ & $0.4 I-5.8$ & $0.5 I-6.5$ \\
\hline Mean \pm SD & $1.52 \pm 0.12$ & $2.12 \pm 0.10^{*}$ & $2.42 \pm 0.15^{*}$ \\
\hline \multicolumn{4}{|c|}{ HDL-cholesterol (mmol/L) } \\
\hline Range & $0.44-3.8$ & $0.14-3.6$ & $0.24-4.8$ \\
\hline Mean \pm SD & $2.85 \pm 0.13$ & $2.66 \pm 0.30 *$ & $2.55 \pm 0.2 I^{*}$ \\
\hline
\end{tabular}

Notes: Values are expressed as mean \pm SD. *Significant change difference from normal control group at $P<0.05$.

Abbreviations: HDL, high-density lipoprotein; LDL, low-density lipoprotein; NC, normal control group; DR(-), diabetics without retinopathy; DR(+), diabetics with retinopathy; SD, standard deviation. 
Table 5 Serum antioxidant enzymes levels of patients with and without diabetic retinopathy

\begin{tabular}{lccl}
\hline Parameter & NC & DR(-) & DR(+) \\
\hline SOD $(\mathrm{U} / \mathrm{mL})$ & $5.44 \pm 1.12$ & $3.12 \pm 0.87^{*}$ & $1.53 \pm 0.14^{*}$ \\
GPx $(\mathrm{mU} / \mathrm{mL})$ & $14.31 \pm 3.14$ & $11.14 \pm 2.2 I^{*}$ & $8.20 \pm 1.84^{*}$ \\
CAT $(\mathrm{U} / \mathrm{mL})$ & $40.13 \pm 5.94$ & $26.43 \pm 3.34^{*}$ & $9.60 \pm 2.14^{*}$ \\
\hline
\end{tabular}

Notes: Values are expressed as mean \pm SD. $*$ Significant change difference from normal control group at $P<0.05$.

Abbreviations: NC, Normal control group; DR(-), diabetics without retinopathy; $\mathrm{DR}(+)$, diabetics with retinopathy; SD, standard deviation. SOD, superoxide dismutase; GPx, glutathione peroxidase; CAT, catalase.

between the retinopathy grade and LDL-cholesterol was observed $\left(r^{2}=+0.019, P<0.05\right)$. In contrary, slightly significant negative correlation between the retinopathy grade and total cholesterol was observed $\left(r^{2}=+0.01732, P<0.05\right)$; however, other parameters showed nonsignificant correlations (Figure 2).

\section{Discussion}

The prevalence of DR in our study was $32.84 \%$. The prevalence of DR in this study was similar to that in the UK prospective diabetes study (37\%), ${ }^{25}$ the Melbourne visual impairment project $(35.7 \%)^{26}$, and our previous study $(36.1 \%){ }^{27}$ it was also very close to that found in a study in the Pima Native Americans in Arizona (31.8\%). ${ }^{28}$ The low prevalence of DR in our study and the Arizona study might be attributed to a diabetes screening program in which regular diabetes screening was offered on a biennial basis to children aged $\geq 5$ years. The prevalence of DR in our study was also higher than that in another study conducted in Hong Kong (28.4\%) in which the subjects were recruited from primary health care clinics. ${ }^{29}$

There are multiple risk factors that can affect the development and progression of DR. In this study, and as has been shown in other studies, the level of glycemic control as measured by $\mathrm{HA}_{1 \mathrm{c}}$ is a marker for both development and progression of DR. The $\mathrm{HA}_{1 \mathrm{c}}$ level was elevated in the $\mathrm{DR}(+)$ patients more than in the DR(-) patients. We also found that the serum fasting blood glucose level was associated with progression in the $\mathrm{DR}(+)$ patients at a higher significance level than in the DR(-) patients. This was in accordance with findings obtained from another study. ${ }^{30}$ Also of interest, it has been reported that the serum postprandial plasma glucose levels determined at 2 hours after the intake of an isocaloric mixed breakfast correlated well with the progression of DR. ${ }^{31}$

The relationship between DR and hypertension was strongly suggested by the results of the United Kingdom Prospective Diabetes Study (UKPDS) trial. ${ }^{32}$ However, the appropriate blood pressure control in diabetes $(\mathrm{ABCD})$ trial revealed no relationship between blood pressure and incidence of DR. ${ }^{33}$ The authors of the ABCD study suggested that the lack of effect might have resulted from the shorter time period of the study, lower average blood pressure control, and poorer glycemic control in the ABCD trial than in the UKPDS. Our results showed that a history of hypertension and higher systolic blood pressure were significantly associated with progression of DR. These data were in accordance with a previous study conducted in China ${ }^{19}$ and consistent

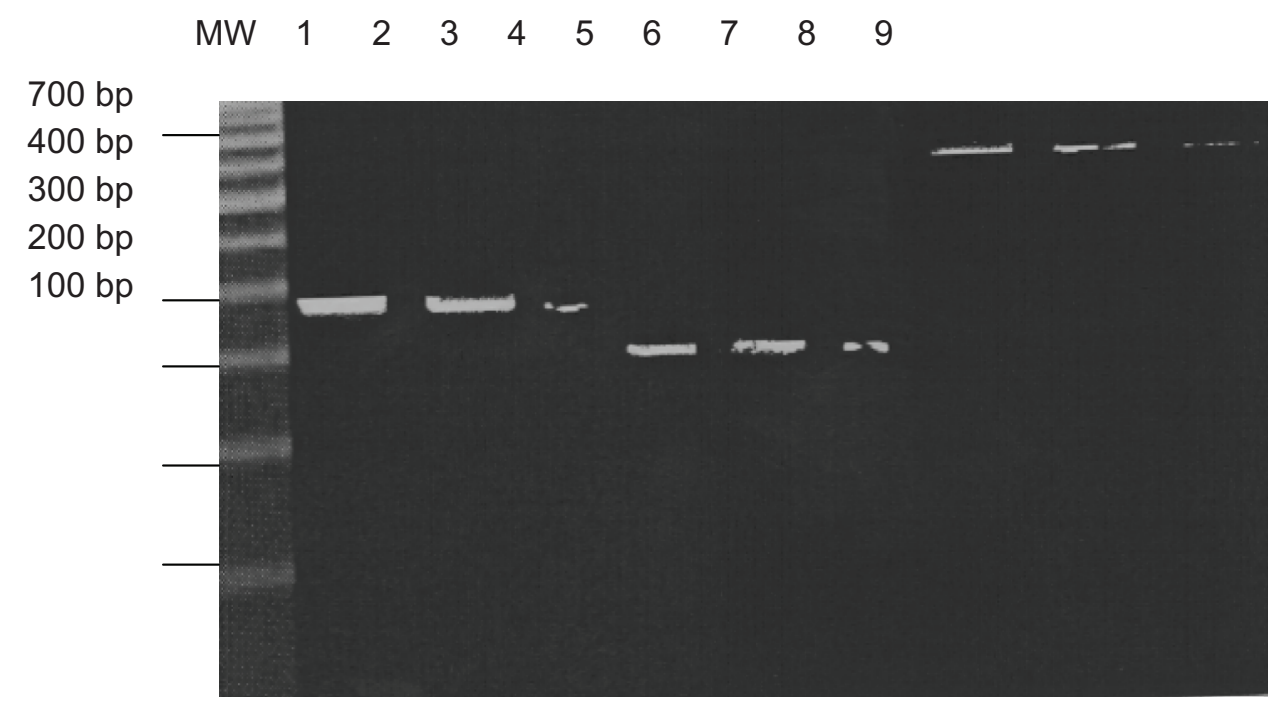

Figure I $2 \%$ agarose gel electrophoresis of PCR product of serum SOD, GPx and CAT.

Notes: Lanes I-3 for SOD, Lanes 4-6 for GPx and Lanes 7-9 for CAT. MW = M.W. DNA 100 bp ladder. The size of SOD gene $=387$ bp. The size of GPx gene = 290 bp. The size of CAT gene $=670$ bp. Lanes I, 4 and 7 are normal control. Lanes 2, 5 and 8 are DR(-) patients. Lanes 3, 6 and 9 are DR(+) patients.

Abbreviations: DR(-), diabetics without retinopathy; DR(+), diabetics with retinopathy; PCR, polymerase chain reaction; SOD, superoxide dismutase; CAT, catalase; GPx, glutathione peroxidase. 

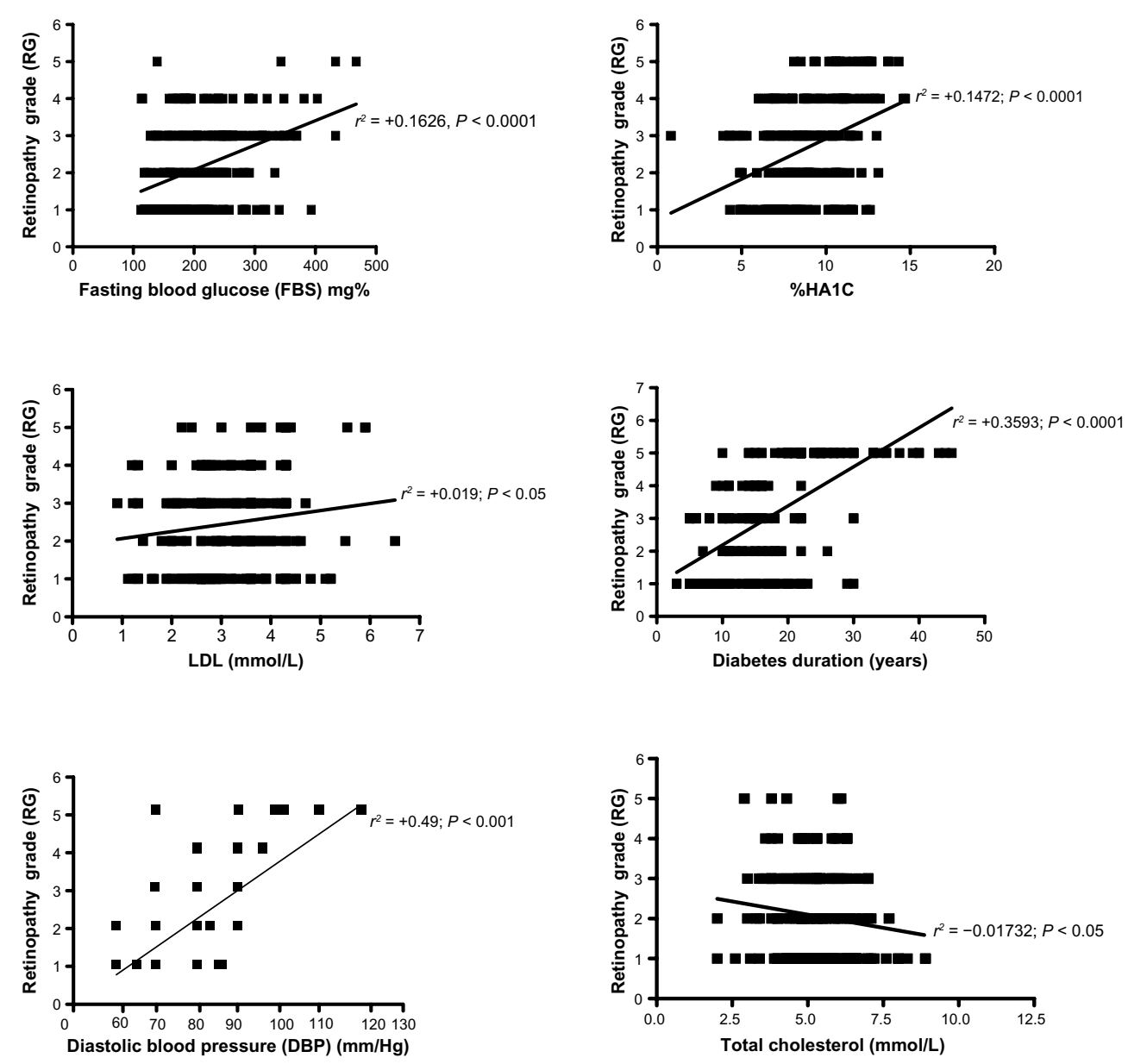

Figure 2 The linear regression analysis revealed a strong significant positive correlation between the retinopathy grade (RG) and the diastolic blood pressure $\left(r^{2}=+0.49\right.$; $P<0.00 \mathrm{I})$, diabetes duration $\left(r^{2}=0.3593 ; P<0.00 \mathrm{I}\right)$, Hemoglobin AIc $\left(\mathrm{HA}_{\mathrm{Ic}}\right) \%\left(r^{2}=+0.1472, P<0.000 \mathrm{I}\right)$ and fasting blood glucose $\left(r^{2}=+0.1626, P<0.000 \mathrm{I}\right)$. A slightly significant positive correlation between the retinopathy grade and low-density lipoprotein-cholesterol was observed $\left(r^{2}=+0.019, P<0.05\right)$. In contrast, slightly significant negative correlation between the retinopathy grade and total cholesterol was observed $\left(r^{2}=+0.01732, P<0.05\right)$.

with the Wisconsin epidemiologic study XXIII of diabetic retinopathy evaluations after 14 years of follow-up. ${ }^{34,35}$

The possible mechanisms by which hypertension affects DR include impaired auto-regulation, hyperperfusion, and up-regulation of the vascular endothelial growth factor expression in retinal endothelial cells. ${ }^{36}$ Improved monitoring and control of hypertension among diabetic patients in the United Arab Emirates, which has been shown to slow the progression of retinopathy and especially among those with poorly controlled diabetes, is strongly recommended. ${ }^{37}$

In our study, we observed that patients who developed DR had a significantly higher BMI. While most previous studies showed no association between BMI and DR, the Nottingham study showed an inverse relationship between BMI and DR in type 2 diabetic patients. ${ }^{38}$ Chan et $\mathrm{al}^{39}$ demonstrated that in Chinese type 2 diabetic patients lean subjects had predominant insulin deficiency and obese subjects had features of metabolic syndrome. The lean patients had the lowest $\mathrm{C}$-peptide and the highest $\mathrm{HA}_{1 \mathrm{c}}$ and hence, higher prevalence of microvascular complications. The association between serum lipid levels and DR has been investigated in many studies; several studies have shown that the serum cholesterol level was associated with increased risk and severity of retinal hard exudates. ${ }^{13,40}$

The use of atorvastatin has been found to be associated with reduction in the severity of hard exudates and subfoveal lipid migration in clinically significant macular edema. ${ }^{41}$ The present study showed significant association between hyperlipidemia and DR. This was in opposition to a previous study that showed no significant association between hyperlipidemia and DR. ${ }^{19}$

Our results showing a significant positive association between $\mathrm{HA}_{1 \mathrm{c}}$ levels and different grades of diabetic retinopathy are consistent with other reports. $\mathrm{HA}_{1 \mathrm{c}}$ levels in diabetic Saudi patients were more than $8 \%$, and there 
was a positive correlation between diabetic retinopathy and hyperlipidemia. It is strongly recommended that glycemic and lipidemic control be widely promoted and that $\mathrm{HA}_{1 \mathrm{c}}$ and lipid profile investigations be carried out routinely. ${ }^{42}$ The results should be compared with those of the Wisconsin Epidemiologic Study of diabetic retinopathy: XXII, which examined the 25-year cumulative progression and regression of diabetic retinopathy (DR) and its relation to various risk factors. ${ }^{9}$ The Wisconsin study revealed that the higher glycated hemoglobin is associated with increased risk of incidence of PDR.

Also, the present study revealed the significant decline in serum SOD, GPx, and CAT antioxidant enzymes among the $\mathrm{DR}(+)$ patients. This may be attributed to the poor glycemic control of those DR patients. The levels of oxidized lipids, DNA and proteins are higher in diabetics, suggesting a diminished capacity to reduce toxic reactive oxygen. ${ }^{43,44}$ These results were concomitant with the decrease of expression of the genes of the mentioned enzymes among the $\mathrm{DR}(+)$ patients.

\section{Conclusion}

DR is prevalent in Saudi patients with type 2 diabetes and associated with poor glycemic control associated with low levels of mRNA expression of antioxidant enzymes. Regular screening is mandatory for early detection and management. More frequent retinopathy screening should be offered to those patients with DR and poor glycemic control in order to prevent the development and progression of DR.

\section{Acknowledgments}

This research was supported by funds provided by grant 986-433 from the Deanship of Scientific Research, Taibah University, Al-Madinah Al-Munawarah, Kingdom of Saudi Arabia. We would like to thank all of our colleagues for their continuous support to conduct our research. Special thanks to our skilful research assistant Mr Wael Barakat, and the laboratory technician Mr Mohamed Abd-Elsamad.

\section{Disclosure}

The authors report no conflicts of interest in this work.

\section{References}

1. Ciulla TA, Amador AG, Zinman B. Diabetic retinopathy and diabetic macular edema: pathophysiology, screening, and novel therapies. Diabetes Care. 2003;26(9):2653-2664.

2. Hallman DM, Huber JC Jr, Gonzalez VH, Klein BE, Klein R, Hanis CL. Familial aggregation of severity of diabetic retinopathy in Mexican Americans from Starr County Texas. Diabetes Care. 2005; 28(5):1163-1168.
3. Uhlmann K, Kovacs P, Boettcher Y, Hammes HP, Paschke R. Genetics of diabetic retinopathy. Exp Clin Endocrinol Diabetes. 2006;114(6): 275-294.

4. Congdon NG, Friedman DS, Lietman T. Important causes of visual impairment in the world today. JAMA. 2003;290(15):2057-2060.

5. Klein R, Klein BE, Moss SE, Davis MD, DeMets DL. The Wisconsin Epidemiologic Study of Diabetic Retinopathy. III. Prevalence and risk of diabetic retinopathy when age at diagnosis is 30 or more years. Arch Ophthalmol. 1984;102(4):527-532.

6. Klein R, Klein BE, Moss SE, Davis MD, DeMets DL. The Wisconsin epidemiologic study of diabetic retinopathy. II. Prevalence and risk of diabetic retinopathy when age at diagnosis is less than 30 years. Arch Ophthalmol. 1984;102(4):520-526.

7. Heintz E, Wiréhn AB, Peebo BB, Rosenqvist U, Levin LA. Prevalence and healthcare costs of diabetic retinopathy: a population-based register study in Sweden. Diabetologia. 2010;53(10):2147-2154.

8. Cheung N, Mitchell P, Wong TY. Diabetic retinopathy. Lancet. 2010; 376(9735): 124.

9. Klein R, Knudtson MD, Lee KE, Gangnon R, Klein BE. The Wisconsin Epidemiologic Study of Diabetic Retinopathy: XXII the twenty-five-year progression of retinopathy in persons with type 1 diabetes. Ophthalmology. 2008;115(11):1859-1868.

10. Effect of intensive therapy on the microvascular complications of type 1 diabetes mellitus. Writing Team for the Diabetes Control and Complications Trial/Epidemiology of Diabetes Interventions and Complications Research Group. JAMA. 2002;287(19):2563-2569.

11. Holman RR, Paul SK, Bethel MA, Matthews DR, Neil HAW. 10-year follow-up of intensive glucose control in type 2 diabetes. $N$ Engl J Med. 2008;359(15):1577-1589.

12. Klein R. Hyperglycemia and microvascular and macrovascular disease in diabetes. Diabetes Care. 1995;18(2):258-268.

13. Chew EY, Klein ML, Ferris FL, et al. Association of elevated serum lipid levels with retinal hard exudates in diabetic retinopathy: Early Treatment Diabetic Retinopathy Study (ETDRS) Report 22. Arch Ophthalmol. 1996;114(9):1079-1084.

14. Fujisawa T, Ikegami H, Yamato E, et al. Association of plasma fibrinogen level and blood pressure with diabetic retinopathy, and renal complications associated with proliferative diabetic retinopathy in Type II diabetes mellitus. Diabet Med. 1999;16(6):522-526.

15. Zhang X, Saaddine JB, Chou CF, Cotch MF, et al. Prevalence of diabetic retinopathy in the United States, 2005-2008. JAMA. 2010;304(6): 649-656.

16. Hammes HP, Kerner W, Hofer S, Kordonouri O, Raile K, Holl RW; DPVWiss Study Group. Diabetic retinopathy in type 1 diabetes- a contemporary analysis of 8784 patients. Diabetologia. 2011;54(8): 1977-1984.

17. American Diabetes Association. Diagnosis and Classification of Diabetes Mellitus. Diabetes Care. 2004.27 Suppl 1:S5-S10.

18. American Diabetes Association. Standards of medical care in diabetes 2008. Diabetes Care. 2008;31 Suppl 1:S12-S54.

19. Tam VH, Lam EP, Chu BC, Tse KK, Fung LM. Incidence and progression of diabetic retinopathy in Hong Kong Chinese with type 2 diabetes mellitus. J Diabetes Complications. 2009;23(3):185-193.

20. Wilkinson CP, Ferris FL 3rd, Klein RE, et al. Proposed international clinical diabetic retinopathy and diabetic macular edema disease severity scales. Ophthalmology. 2003;110:1677-1682.

21. Friedwald WT, Levy RI, Fredrickson DS. Estimation of the concentration of low density lipoprotein cholesterol in plasma, without use of the preparative ultracentrifuge. Clin Chem. 1972;18(6):499-502.

22. Lawrence RA, Burk RF. Glutathione peroxidase activity in seleniumdeficient rat liver. 1976. Biochem Biophys Res Commun. 2012;425(3): 503-509.

23. Aebi H. Catalase in vitro. Methods Enzymol. 1984;105:121-126.

24. Oyanagui Y. Reevaluation of assay methods and establishment of kit for superoxide dismutase activity. Anal Biochem. 1984;142(2): 290-296.

25. Stratton IM, Kohner EM, Aldington SJ, et al. UKPDS 50: Risk factors for incidence and progression of retinopathy in Type 2 diabetes over 6 years from diagnosis. Diabetologia. 2001;44(2):156-163. 
26. Dimitrov PN, Mukesh BN, McCarty CA, Taylor HR. Five-year incidence of diabetic retinopathy in the Melbourne Visual Impairment Project. Clin Experiment Ophthalmol. 2003;31(5):397-402.

27. El-Bab MF, Shawky N, Al-Sisi A, Akhtar M. Retinopathy and risk factors in diabetic patients from Al-Madinah Al-Munawarah in the Kingdom of Saudi Arabia. Clin Ophthalmol. 2012;6:269-276.

28. Looker HC, Krakoff J, Knowler WC, Bennett PH, Klein R, Hanson RL. Longitudinal studies of incidence and progression of diabetic retinopathy assessed by retinal photography in pima Indians. Diabetes Care. 2003;26(2):320-326.

29. Tam TK, Lau CM, Tsang LC, Ng KK, Ho KS, Lai TC. Epidemiological study of diabetic retinopathy in a primary care setting in Hong Kong. Hong Kong Med J. 2005;11(6):438-444.

30. Chen MS, Kao CS, Fu CC, Chen CJ, Tai TY. Incidence and progression of diabetic retinopathy among non-insulin dependent diabetic subjects: A 4-year follow-up. Int JEpidemiol. 1995;24(4):787-795.

31. Shiraiwa T, Kaneto H, Miyatsuka T, et al. Postprandial hyperglycemia is a better predictor of the progression of diabetic retinopathy than $\mathrm{HbA}_{1 \mathrm{c}}$ in Japanese type 2 diabetic patients. Diabetes Care. 2005;28(11): 2806-2807.

32. Tight blood pressure control and risk of macrovascular and microvascular complications in type 2 diabetes: UKPDS 38. UK Prospective Diabetes Study Group. BMJ. 1998;317(160):703-713.

33. Schrier RW, Estario RO, Jeffers B. Appropriate blood pressure control in NIDDM (ABCD) Trial. Diabetologia. 1996;39(12):1646-1654.

34. Leske MC, Wu SY, Hennis A, et al Barbados Eye Study Group. Hyperglycemia, blood pressure, and the 9-year incidence of diabetic retinopathy: the Barbados Eye Studies. Ophthalmology. 2005;112(5): 799-805.

35. Klein R, Knudtson MD, Lee KE, Gangnon R, Klein BE. The Wisconsin Epidemiologic Study of Diabetic Retinopathy XXIII: the twenty-fiveyear incidence of macular edema in persons with type 1 diabetes. Ophthalmology. 2009;116(3):497-503.
36. Srivastava BK. Rema M. Does hypertension play a role in diabetic retinopathy? J Assoc Physicians India. 2005;53:803-808.

37. Bhatnagar A, Ghauri AJ, Hope-Ross M, Lip PL. Diabetic retinopathy in pregnancy. Curr Diabetes Rev. 2009;5(3):151-156.

38. Janghorbani M, Jones RB, Murray KJ, Allison SP. Incidence of risk factors for diabetic retinopathy in diabetic clinic attenders. Ophthalmic Epidemiol. 2001;8(5):309-325.

39. Chan WB, Tong PC, Chow CC, et al. The associations of body mass index, C-peptide and metabolic status in Chinese Type 2 diabetic patients. Diabetic Med. 2004;21:349-353.

40. Klein BE, Moss SE, Klein R, Surawicz TS. Wisconsin Epidemiologic Study of Diabetic Retinopathy: XIII. Relationship of serum cholesterol to retinopathy and hard exudates. Ophthalmology. 1991;98(8): $1261-1265$

41. Gupta A, Gupta V, Thapar S, Bhansali A. Lipid lowering drug atorvastatin as an adjunct in the management of diabetic macular edema. Am J Ophthal. 2004;137(4):675-682.

42. Carson AP, Reynolds K, Fonseca VA, Muntner P. Comparison of $A_{10}$ and fasting glucose criteria to diagnose diabetes among US adults. Diabetes Care. 2010;33:95-97.

43. Elchuri S, Oberley TD, Qi W, et al. CuZn-SOD deficiency leads to persistent and widespread oxidative damage and hepatocarcinogenesis later in life. Oncogene. 2005;24(3):367-380.

44. Muller FL, Song W, Liu Y, et al. Absence of CuZn superoxide dismutase leads to elevated oxidative stress and acceleration of age dependent skeletal muscle atrophy. Free Radic Biol Med. 2006;40(11): 1993-2004.

45. Matsunami T, Sato Y, Sato T, Yukawa M. Antioxidant status and lipid peroxidation in diabetic rats under hyperbaric oxygen exposure. Physiol Res. 2010;59(1):97-104.
International Journal of General Medicine

\section{Publish your work in this journal}

The International Journal of General Medicine is an international, peer-reviewed open-access journal that focuses on general and internal medicine, pathogenesis, epidemiology, diagnosis, monitoring and treatment protocols. The journal is characterized by the rapid reporting of reviews, original research and clinical studies across all disease areas.

\section{Dovepress}

A key focus is the elucidation of disease processes and management protocols resulting in improved outcomes for the patient.The manuscript management system is completely online and includes a very quick and fair peer-review system. Visit http://www.dovepress.com/ testimonials.php to read real quotes from published authors. 